\title{
Penyuluhan Motivasi Kewirausahaan Bagi Masyarakat Desa Tanjung Raya Kecamatan Sukamerindu Kabupaten Lahat
}

\author{
Wita Farla ${ }^{1 *}$, Muhammad Ichsan Hadjri ${ }^{1}$ dan lisnawati ${ }^{1}$ \\ ${ }^{1}$ Fakultas Ekonomi, Universitas Sriwijaya, Sumatera Selatan, Indonesia \\ *Email korespondensi: witafarla@fe.unsri.ac.id; Phone: +62811710181
}

Info Artikel: Diterima: 21 Januari 2021; Disetujui: 07 Juni 2021; Dipublikasi: 08 November 2021

\begin{abstract}
Abstrak: Motivasi adalah keadaan dalam diri seseorang yang mendorong individu untuk melakukan kegiatan tertentu guna mencapai tujuan. Seorang individu akan melihat berbagai peluang, kesempatan, serta kekuatan yang dimilikinya untuk mencapai tujuannya. Motivasi yang dimiliki oleh individu akan mempengaruhi keputusan-keputusan. Salah satu keputusan yang dibuat oleh individu adalah keputusan untuk berwirausaha.Melalui kegiatan wirausaha, seseorang dapat mewujudkan tujuannya.Banyak individu yang sudah memiliki kemampuan atau keahlian untuk berwirausaha, tapi masih kurang tertarik untuk melakukan kegiatan wirausaha atau tidak terdorong untuk melakukan pengembangan dari usaha yang sudah dijalankan.Banyak masyarakat yang melakukan kegiatan usaha hanya sekadarnya saja, padahal jika masyarakat mau belajar dan mengembangkan potensi diri, maka kegiatan menjalankan usaha dapat dijadikan sebagai profesi, yaitu profesi pengusaha atau wirausahawan. Hal ini juga terjadi pada masyarakat Desa Tanjung Raya Kecamatan Sukamerindu Kabupaten Lahat yang merupakan salah satu desa penghasil kopi.Masih banyak masyarakat desa Tanjung Raya yang melakukan kegiatan usaha seadanya.Dengan demikian, perlu diberi dorongan atau motivasi kepada para masyarakat tersebut untuk mengembangkan jiwa kewirausahaan dan usahanya.
\end{abstract}

Kata Kunci: Motivasi; Kewirausahaan; Wirausaha

Kutipan:

Farla, W., Hadjri, M.I., \& lisnawati. (2021). Penyuluhan Motivasi Kewirausahaan Bagi Masyarakat Desa Tanjung Raya Kecamatan Sukamerindu Kabupaten Lahat. Sricommerce: Journal of Sriwijaya Community Services, 2(2): 133-138. DOI: https://doi.org/10.29259/jscs.v2i2.60

\section{PENDAHULUAN}

Motivasi berasal dari bahasa latin "movere" yang artinya bergerak. Motivasi didefinisikan sebagai kekuatan yang ada dalam diri seseorang yang menimbulkan kegigihan individu untuk melakukan kegiatan tertentu guna mencapai tujuan (Rainey, 2014). Seorang individu akan melihat berbagai peluang, kesempatan, serta kekuatan yang dimilikinya untuk mencapai tujuannya. Menurut Barba-Sánchez \& Atienza-Sahuquillo (2012), motivasi yang dimiliki oleh individu akan mempengaruhi keputusan-keputusan. Salah satu keputusan yang dibuat oleh individu adalah keputusan untuk berwirausaha.

Wirausaha merupakan seseorang yang secara mandiri melakukan kegiatan produktif dengan memanfaatkan peluang untuk menciptakan usaha baru (Ernani Hadiyati, 2011). Melalui kegiatan wirausaha, seseorang dapat mewujudkan tujuannya. Keinginan untuk memperoleh keuntungan 
merupakan salah satu tujuan yang ingin dicapai oleh setiap wirausahawan. Keinginan ini perlu mendapat dorongan atau motivasi baik dari diri individu itu sendiri maupun dari luar diri individu. Banyak individu yang sudah memiliki kemampuan atau keahlian untuk berwirausaha, tapi masih kurang tertarik untuk melakukan kegiatan wirausaha atau tidak terdorong untuk melakukan pengembangan dari usaha yang sudah dijalankan.

Motivasi untuk berwirausaha merupakan semangat atau dorongan dalam diri seseorang untuk menciptakan pekerjaan dengan melihat peluang, dimana individu tersebut harus berinovatif, berani mengambil resiko, dan memiliki tujuan memperoleh laba (Oblivia \& Indriyani, 2013). Individu dengan motivasi berwirausaha yang tinggi akan terus melakukan inovasi-inovasi dalam usahanya. Disisi lain, banyak masyarakat yang melakukan kegiatan usaha hanya sekadarnya saja, padahal jika masyarakat mau belajar dan mengembangkan potensi diri, maka kegiatan menjalankan usaha dapat dijadikan sebagai profesi, yaitu profesi pengusaha atau wirausaha dan dari profesi ini dapat membentuk karir seseorang (Anggarini et.al., 2021).

Berdasarkan data Kabupaten Lahat dalam Angka Tahun 2019, pada tahun 2018 luas perkebunan kopi di Kabupaten Lahat memiliki proporsi terbesar jika dibandingkan dengan tanaman lainnya. Data Kabupaten Lahat dalam Angka Tahun 2019 juga menunjukkan bahwa jumlah usaha penggilingan kopi di Kabupaten Lahat sebanyak 649 unit usaha. Jumlah ini merupakan jumlah unit usaha terbanyak yang ada di Kabupaten Lahat. Selain itu terdapat juga unit usaha bubuk kopi sebanyak 116 unit usaha. Salah satu desa yang berada di Kabupaten Lahat adalah Desa Tanjung Raya yang berada di Kecamatan Sukamerindu. Kecamatan Sukamerindu sendiri memiliki luas perkebunan kopi sebesar 4.675.000 hektar dan Desa Tanjung Raya merupakan salah satu desa penghasil kopi.

Masih banyak masyarakat desa Tanjung Raya yang melakukan kegiatan usaha seadanya, misalnya hanya menjadi petani kopi. Para petani kopi tersebut hanya menjual biji kopi dalam bentuk utuh atau dijadikan bubuk kopi. Melihat keadaan tersebut, maka di Desa Tanjung Raya Kecamatan Sukamerindu masih terdapat potensi untuk mengembangan unit-unit usaha yang berkaitan dengan biji kopi. Masyarakat atau petani perlu diberi dorongan atau motivasi untuk mengembangkan varian olahan dari biji kopi tersebut, misalnya dijadikan bahan pewangi ruangan karena saat ini sedang tren pewangi ruangan aroma kopi atau bubuk kopi dapat dijadikan masker untuk kecantikan. Masyarakat ini perlu diberi motivasi untuk mengembangkan jiwa kewirausahaannya sehingga terus bersemangat dalam menjalankan usaha serta mampu memunculkan ide-ide kreatif dan inovatif untuk menjaga kelangsungan usahanya. Berdasarkan uraian ini, permasalahan yang akan diangkat melalui kegiatan penyuluhan ini adalah bagaimana cara meningkatkan motivasi kewirausahaan masyarakat Desa Tanjung Raya Kecamatan Sukamerindu Kabupaten Lahat dalam mengembangkan usahanya.

\section{METODE}

Khalayak sasaran dalam kegiatan pengabdian masyarakat ini adalah masyarakat Desa Tanjung Raya Kecamatan Sukamerindu Kabupaten Lahat yang berjumlah 25 orang. Khalayak sasaran ini merupakan masyarakat desa yang berprofesi sebagai petani kopi atau pemilik usaha kecil. Jika dilihat dari segi pengetahuan, para khalayak sasaran ini masih memiliki pemahaman yang rendah mengenai kegiatan wirausaha dan kurang termotivasi untuk mengembangkan usahanya. Bahan yang digunakan dalam kegiatan pengabdian masyarakat ini berupa materi atau bahan ajar yang akan diberikan kepada para peserta. Penyampaian materi diberikan langsung oleh tim pelaksana, dimana materi mengenai motivasi kewirausahaan ini merupakan materi yang sudah biasa disampaikan oleh tim pelaksana pada saat kegiatan pengajaran di kampus.

Kegiatan pengabdian masyarakat ini dilakukan dengan dua metode, yaitu paparan materi dan diskusi dengan peserta. Materi yang telah dipersiapkan dipaparkan oleh tim pelaksana. Materi ini berisi mengenai konsep motivasi dan kewirausahaan. Selanjutnya, dilakukan kegiatan tanya jawab atau diskusi dengan peserta. Evaluasi dilakukan setelah kegiatan inti dari kegiatan pengabdian kepada masyarakat dilakukan dengan cara meminta respon dari para peserta mengenai 
pemahaman peserta mengenai materi penyuluhan dan menanyakan sikap peserta terhadap kegiatan pengabdian tersebut. Peserta juga diminta untuk memberikan penilaian terhadap pelaksanaan kegiatan seperti topik atau materi yang disampaikan, cara penyajian narasumber, dan alat bantu yang digunakan.

Gambar berikut menunjukkan beberapa langkah yang digunakan untuk pemecahan masalah mengenai cara meningkatkan motivasi kewirausahaan masyarakat Desa Tanjung Raya Kecamatan Sukamerindu Kabupaten Lahat.

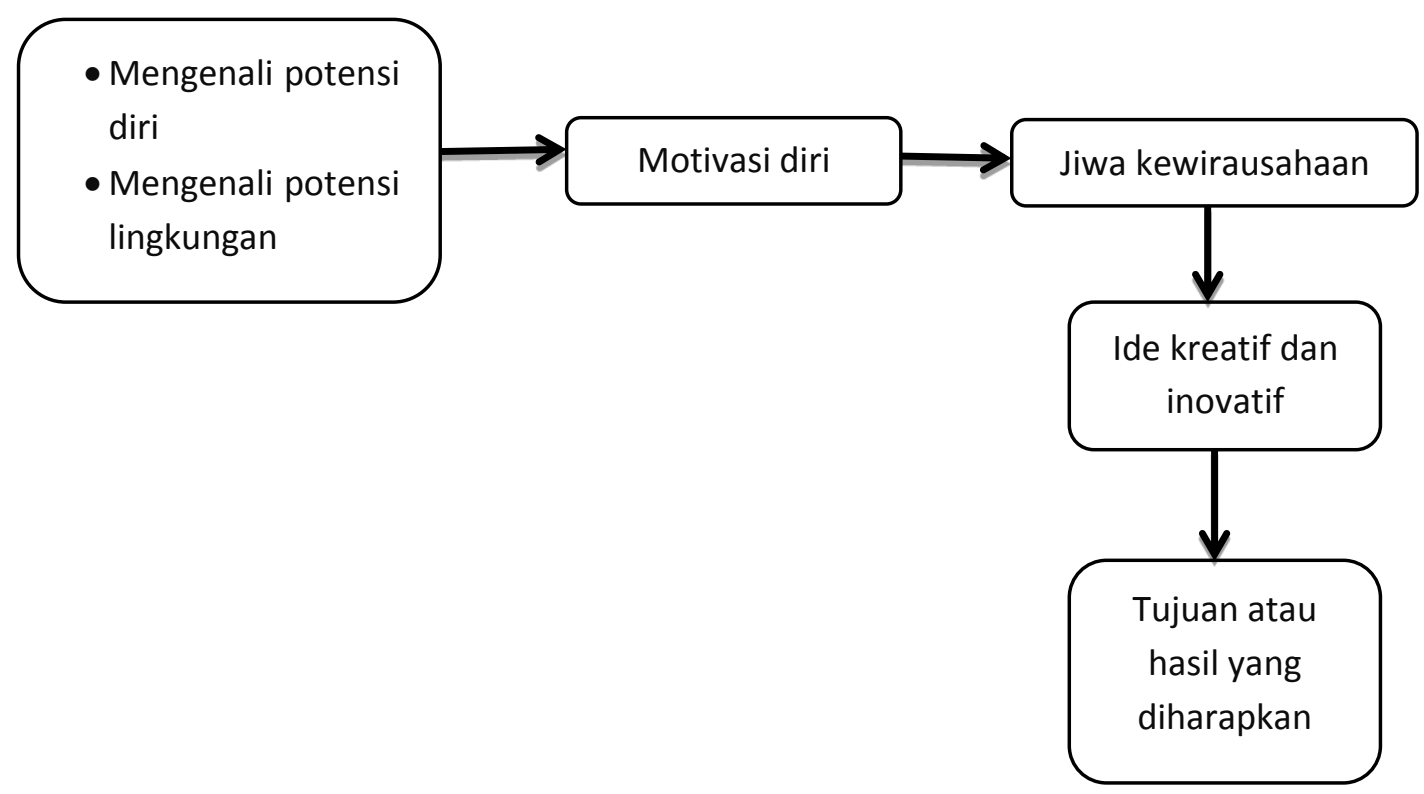

Gambar 1. Kerangka Pemecahan Masalah

Gambar 1 menunjukkan lima tahapan dalam menyelesaikan masalah. Tahap pertama, mengenali potensi diri dan potensi lingkungan. Pada tahap ini masyarakat diharapkan mengidentifikasi kelebihan yang dimiliki oleh diri sendiri, misalnya memiliki keahlian dalam teknik menjual produk atau memiliki modal yang cukup untuk menjalankan usaha. Selain mengenali potensi diri, masyarakat juga harus mampu untuk mengenali potensi lingkungan sekitar. Di Desa Tanjung Raya terdapat banyak kebun kopi dan masyarakat dapat mengambil peluang dari potensi alam tersebut.

Tahap kedua, motivasi diri. Motivasi merupakan elemen penting yang mendorong seseorang untuk berperilaku. Perilaku ini dikaitkan dengan pemenuhan kebutuhan dan keinginan (Dweck, 2017). Setiap orang pasti memiliki kebutuhan dan keinginan yang sebagiannya harus segera dipenuhi. Untuk memenuhi kebutuhan dan keinginan tersebut, seseorang akan mengarahkan perilakunya. Pada saat kebutuhan meningkat, perilaku yang diharapkan dari masyarakat Desa Tanjung Raya adalah melakukan kegiatan bisnis atau usaha.

Tahap ketiga, jiwa kewirausahaan. Jiwa kewirausahaan merupakan sikap dan kemampuan seseorang dalam menjalankan usaha dengan tujuan untuk memperoleh keuntungan dan memberikan manfaat bagi pihak lain (Suroto et al., 2016). Jiwa kewirausahaan tidak muncul dengan seketika, tapi membutuhkan proses yang cukup lama, salah satunya dengan pendidikan kewirausahaan (Indah Kusuma, 2017). Penyuluhan yang diberikan kepada masyarakat Desa Tanjung Raya mengenai kewirausahaan merupaka salah satu bentuk dari pendidikan kewirausahaan.

Tahap keempat, ide kreatif dan inovatif. Kreatifitas merupakan hal penting dalam berwirausaha dengan melihat peluang-peluang bisnis yang baru. Kreatifitas merupakan salah satu keahlian yang diperlukan untuk mencapai kesuksesan dalam berbisnis dan 
merupakan sumber dari inovasi. Kreatifitas tidak hanya dibutuhkan dalam berwirausaha tapi juga memegang peranan penting pada saat penyusunan keputusan-keputusan strategi bisnis (Tu \& Yang, 2013). Dengan demikian, kreatifitas selain akan menentukan kesuksesan bisnis dan juga dibutuhkan dalam menciptakan bisnis baru.

Tahap kelima, tujuan atau hasil yang diharapkan. Melalui penyuluhan ini diharapkan masyarakat terdorong untuk mengembangkan usahanya sehingga tumbuh jiwa kewirausahaan dan pada akhirnya akan meningkatkan kesejahteraan masyarakat. Tujuan dari berwirausaha adalah memperoleh keuntungan dan keberlangsungan usaha (Suroto et al., 2016). Dengan demikian, kesejahteraan masyarakat akan terwujud jika usaha yang dijalankan memperoleh keuntungan dan dapat bertahan hidup.

\section{HASIL DAN PEMBAHASAN}

\subsection{Gambaran Lokasi Kegiatan}

Kegiatan pengabdian kepada masyarakat ini dilaksanakan di Desa Tanjung Raya Kecamatan Sukamerindu Kabupaten Lahat Sumatera Selatan yang merupakan salah satu desa penghasil kopi. Sebagian besar masyarakat di Desa Tanjung Raya berprofesi sebagai petani kopi dan melakukan kegiatan usaha bisnis mulai dari skala kecil hingga menengah.

\subsection{Pelaksanaan Kegiatan}

Desa Tanjung Raya Kecamatan Sukamerindu merupakan salah satu desa penghasil kopi di Kabupaten Lahat. Berdasarkan pengamatan awal, masih banyak masyarakat Desa Tanjung Raya yang melakukan kegiatan usaha seadanya. Misalnya, para petani kopi yang hanya menjual biji kopi dalam bentuk utuh atau hanya dijadikan bubuk kopi. Padahal biji kopi bisa dijadikan banyak produk turunannya seperti untuk kosmetik kecantikan, pengharum ruangan, tambahan pada olahan makanan, dan lain sebagainya. Oleh karena itu, masyarakat desa perlu diberi penyuluhan mengenai motivasi berwirausaha agar potensi alam yang dimiliki bisa dimanfaatkan secara maksimal. Selain itu, kegiatan penyuluhan diharapkan dapat memunculkan ide-ide kreatif dan inovatif dalam mengembangkan varian olahan dari kopi tersebut.

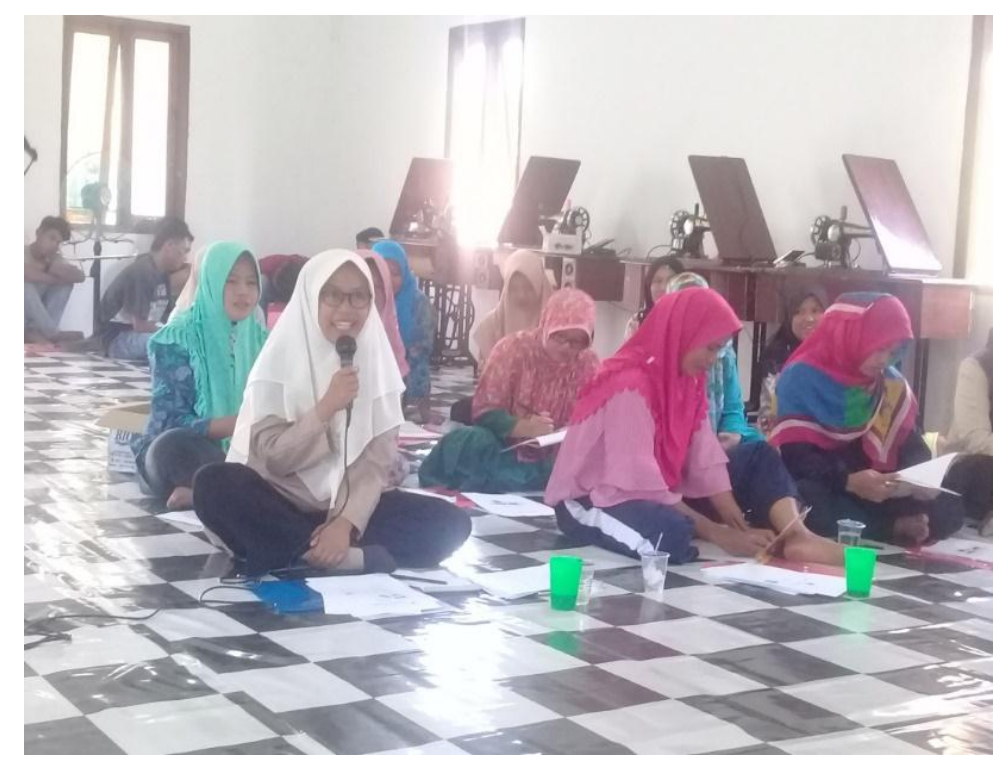

Gambar 2. Diskusi antara pemateri dengan peserta

Seorang wirausaha harus jeli dalam melihat peluang-peluang bisnis dan selalu membuka diri terhadap saran ataupun masukan untuk perubahan yang positif sehingga pada akhirnya akan membawa bisnis tersebut untuk terus tumbuh (Rintan Saragih, 2017). Motivasi berwirausaha 
merupakan semangat atau dorongan yang ada dalam diri seseorang untuk menciptakan pekerjaan dengan melihat peluang, dimana individu tersebut harus berinovasi, berani mengambil resiko, dan memiliki tujuan untuk memperoleh laba (Oblivia \& Indriyani, 2013). Peluang didapat dengan melihat lingkungan sekitar dan setiap orang dapat memanfaatkan celah peluang usaha atau bisnis di lingkungan sekitarnya.

Masyarakat Desa Tanjung Raya dapat melakukan inovasi-inovasi terhadap produk kopi. Inovasi merupakan suatu proses dimana peluang-peluang usaha berasal dari ide-ide kreatif sehingga menghasilkan sesuatu yang bermanfaat bagi orang banyak serta mendatangkan keuntungan. Menurut (Hartini, 2012) inovasi merupakan proses menciptakan sesuatu yang baru baik produk baru atau proses baru. Hasil penelitian (Curatman et al., 2016) mengemukakan bahwa melalui inovasi produk sebuah usaha atau bisnis dapat meningkatkan keunggulan bersaingnya. Di Desa Tanjung Raya terdapat banyak pelaku usaha kecil dan menengah yang mengolah produk kopi. Salah satu cara agar usaha yang dijalankan tetap mendatangkan laba yang besar dan tetap bertahan dalam persaingan usaha yang ketat, pelaku usaha kopi harus terus melakukan inovasiinovasi baik dari sisi produk maupun dari proses.

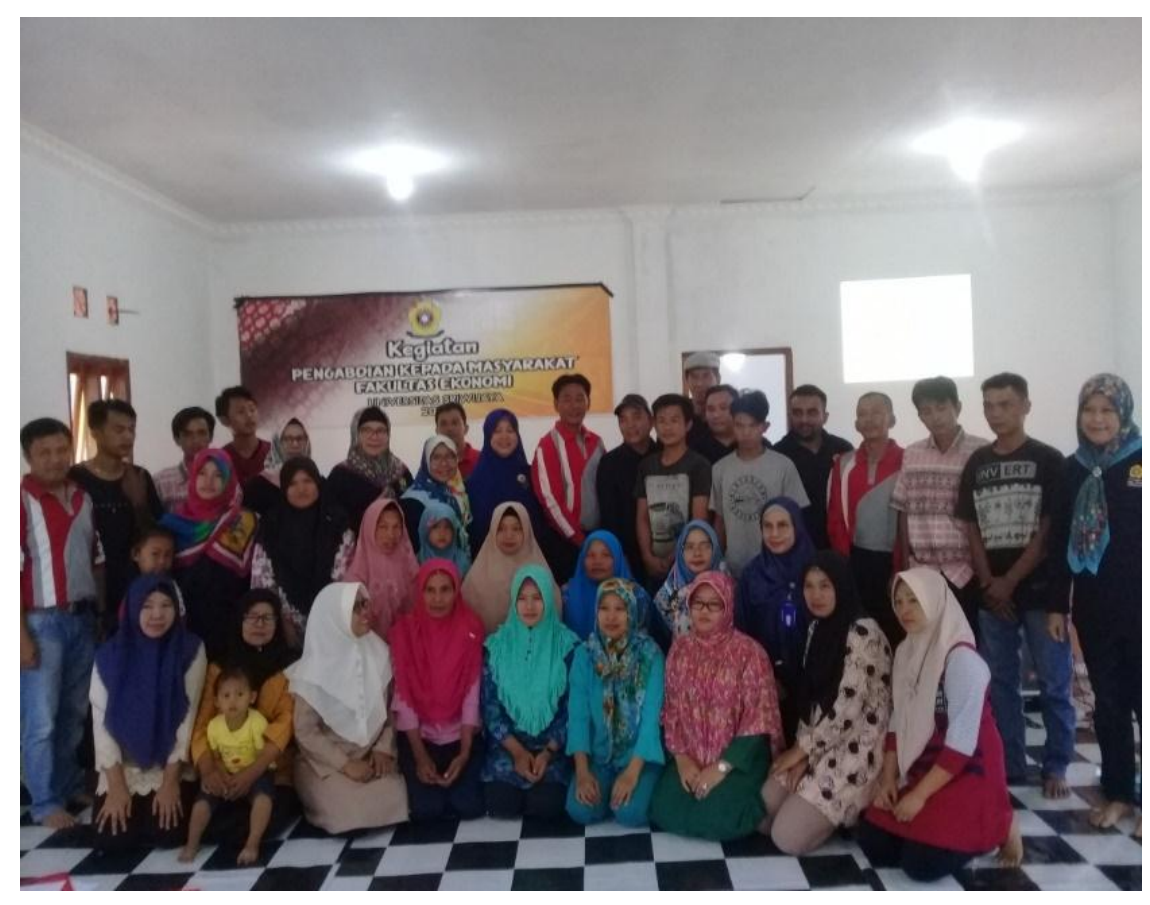

Gambar 3. Foto bersama pemateri dengan peserta

Para pelaku usaha juga harus bersikap fleksibel, artinya selalu menyesuiakan diri dengan perubahan lingkungan dan keinginan konsumen (Purnomo, 2017). Lingkungan yang terus berubah menuntut pengusaha untuk cepat tanggap. Beberapa contoh keinginan konsumen seperti menginginkan kualitas yang baik, harga yang bersaing, pelayanan yang cepat dan ramah, kecepatan pengantaran barang, dan lain sebagainya. Jika pelaku bisnis tidak tanggap terhadap keinginan dan perubahan lingkungan ini, maka kosumen dapat pindah ke toko yang lain. Dengan demikian, tujuan dari kegiatan kewirausahaan yang salah satunya adalah mendapatkan laba menjadi tidak terwujud. Sebaliknya, usaha atau bisnis yang terus mendapatkan laba dapat mengembangkan dirinya menjadi usaha yang lebih besar lagi sehingga usaha yang dijalankan dapat bertahan hidup.

Hasil dari kegiatan penyuluhan ini adalah adanya pemahaman masyarakat mengenai caracara yang dilakukan agar dapat mendorong diri sendiri dalam memunculkan ide-ide kreatif dan inovatif dalam pengolahan biji kopi sehingga usaha yang dimiliki dapat terus berkembang. Masyarakat telah dapat mengidentifikasi potensi-potensi yang dimiliki oleh diri senidri serta lingkungan sekitar. Masyarakat juga telah memahami mengenai jiwa kewirausahaan yang diperlukan dalam menjalankan usaha atau bisnis. 


\section{SIMPULAN}

Kesimpulan yang diambil dari kegiatan pengabdian masyarakat ini adalah sebagian besar masyarakat Desa Tanjung Raya Kecamatan Sukamerindu Kabupaten Lahat khususnya yang memiliki usaha atau bisnis belum memiliki tingkat motivasi yang tinggi dalam mengelola usahanya sehingga usaha atau bisnis yang dijalankan hanya seadanya saja.

Berdasarkan kesimpulan tersebut, maka saran yang dapat diberikan kepada para pelaku usaha adalah agar para pelaku usaha di Desa Tanjung Raya Kecamatan Sukamerindu Kabupaten Lahat perlu diberikan banyak pelatihan mengenai cara mengelola usaha atau bisnis dengan baik. Selain itu, supaya usaha atau bisnis yang dijalankan oleh masyarakat Desa Tanjung Raya Kecamatan Sukamerindu Kabupaten Lahat dapat terus berkembang diperlukan pembinaan yang lebih banyak dari Pemerintah Daerah setempat.

\section{UCAPAN TERIMA KASIH (ACKNOWLEDGMENTS)}

Terima kasih kepada Universitas Sriwijaya yang telah mendanai kegiatan pengabdian kepada masyarakat ini. Terima kasih juga kepada Kepala Desa Tanjung Raya Kecamatan Sukamerindu Kabupaten Lahat, seluruh pihak yang telah membantu, serta peserta kegiatan pengabdian kepada masyarakat ini.

\section{REFERENSI}

Anggarini, D., Nani, D., \& Aprianto, W. (2021). Penguatan Kelembagaan dalam Rangka Peningkatan Produktivitas Petani Kopi pada GAPOKTAN Sumber Murni Lampung (SML). Sricommerce: Journal of Sriwijaya Community Services, 2(1), 59-66. doi:https://doi.org/10.29259/jscs.v2i1.59.

Barba-Sánchez, V., \& Atienza-Sahuquillo, C. (2012). Entrepreneurial behavior: Impact of motivation factors on decision to create a new venture. Investigaciones Europeas de Direccion y Economia de La Empresa. 18, 132-138. https://doi.org/10.1016/S1135-2523(12)70003-5.

Curatman, A., Rahmadi, Maulany, S., \& Ikhsani, M. M. (2016). Analisis Faktor-faktor Pengaruh Inovasi Produk yang Berdampak pada Keunggulan Bersaing UKM Makanan dan Minuman di Wilayah Harjamukti Kota Cirebon. Jurnal Logika, 18(3), 61-75.

Dweck, C. S. (2017). From needs to goals and representations: Foundations for a unified theory of motivation, personality, and development. Psychological Review. https://doi.org/10.1037/rev0000082.

Ernani, H. (2011). Kreativitas dan Inovasi Berpengaruh Terhadap Kewirausahaan Usaha Kecil. Jurnal Manajemen Dan Kewirausahaan, 13, 8-16. https://doi.org/10.9744/jmk.13.1.8-16.

Hartini, S. (2012). Peran Inovasi: Pengembangan Kualitas Produk dan Kinerja Bisnis. Jurnal Manajemen Dan Kewirausahaan, 14(1). https://doi.org/10.9744/jmk.14.1.83-90.

Indah, K. A. (2017). Strategi manajemen sekolah dasar dalam menumbuhkan jiwa kewirausahaan. JURNAL JPSD ( Jurnal Pendidikan Sekolah Dasar ), 4(1), 77-86.

Oblivia, V., \& Indriyani, R. (2013). Analisa Pengaruh Motivasi Berwirausaha Dan Inovasi Produk Terhadap Pertumbuhan Usaha Kerajinan Gerabah Di Lombok Barat. Agora, 1(1).

Purnomo, A. (2017). Penguatan Kewirausahaan dalam Meningkatkan Daya Saing UKM Produk Unggulan di Kota Bandar Lampung. SOSIALITA: Jurnal IImu Administrasi, 9(2), 64-72.

Rainey, H. G. (2014). Motivation and Motivation Theory. Understanding and Managing Public Organizations, 257-296.

Rintan, S. (2017). Membangun usaha kreatif, inovatif dan bermanfaat melalui penerapan kewirausahaan. Jurnal Kewirausahaan, 3(DESEMBER), 26-34. http://jklmii.org.

Suroto, B., Rizal, N., \& Rahman, F. (2016). Identifikasi Jiwa Kewirausahaan Mahasiswa. Jurnal Benefita, 1(3), 154. https://doi.org/10.22216/jbe.v1i3.495.

Tu, C., \& Yang, S. (2013). The Role of Entrepreneurial Creativity in Entrepreneurial Processes. International Journal of Innovation, Management and Technology. 4(2), 286-289. https://doi.org/10.7763/ijimt.2013.v4.408. 